\title{
The role of the podiatrist in falls prevention
}

\author{
Olga Frankowski \\ From Society of Chiropodists and Podiatrists Annual Conference 2010 \\ Bournemouth, UK. 21-23 October 2010
}

\section{Introduction}

With 1 in 3 people aged 65 or over suffering a fall at least once a year, rising to 1 in 2 in those over $80 \mathrm{yrs}$, falls alone are estimated to cost the NHS $£ 4.3$ million per day, amounting to $£ 1.7$ billion per year. The aim of this poster is to provide an overview of 'The role of the podiatrist in falls prevention'.

\section{Methods}

Critical literature review

\section{Results}

With over 400 separate risk factors for falls described in the literature to include a history of falls, mobility impairment, muscle weakness, gait deficit, and polypharmacy, a multifactorial intervention approach is recommended. This said however, the role of the podiatrist in falls prevention is not always recognized or fully understood.

\section{Discussion}

Based upon individual risk factors, podiatrists have an important role to in play in reducing the risk of falls by means of foot health care itself, patient education, health promotion, rehabilitation and mobility. This includes assessing and treating foot pain, identifying and correcting underlying biomechanical and gait abnormalities, prescribing exercise programmes and issuing foot health and footwear advice. Within falls prevention teams or services the role of the podiatrist can further involve undertaking the training of other clinical staff in the recognition of medical factors influencing postural stability, gait and footwear, and promoting the role of the podiatrist.

\section{Implications for practice}

There is a need for podiatrists to actively market podiatry services with particular emphasis on their roles and

University of Salford, Salford, UK responsibilities. Further strategies are also needed to enhance the role of the podiatrist in falls prevention in a bid to further improve podogeriatric care. This would aid to prevent unnecessary injury or trauma, improve quality of life, reduce the incidence of falls and lower morbidity and mortality rates as a direst result of a fall.

Published: 20 December 2010

doi:10.1186/1757-1146-3-S1-P10

Cite this article as: Frankowski: The role of the podiatrist in falls

prevention. Journal of Foot and Ankle Research 2010 3(Suppl 1):P10.
Submit your next manuscript to BioMed Central and take full advantage of:

- Convenient online submission

- Thorough peer review

- No space constraints or color figure charges

- Immediate publication on acceptance

- Inclusion in PubMed, CAS, Scopus and Google Scholar

- Research which is freely available for redistribution
() Biomed Central

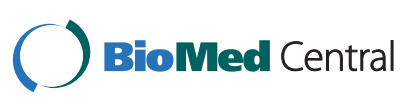

